\title{
Summary Progress Refort for Fiscal Year 1976 and the Transition Quarter Describing Technical Assistance Work for the Division of Systems Safety, U.S. Nuclear Regulatory Commission
}

\author{
Prepared for the
}

U.S. Nuclear Regulatory Commission

Office of Nuclear Reactor Regulation

Under Interagency Agreement ERDA 40-544-75 
$-\cdots . .$.

BLANK PAGE

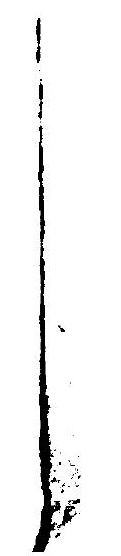


ORVL/MREG-6

Contract No. $6-7: 05-e n g-26$

Engineering Technology Division

\begin{abstract}
SUIYARY PROGRESS REPORT FOR FISCAL YEAR 1976
AND THE TRANSITION QLARTER DESCRIB!SC, TECENICAL ASSISTANCE WORK FOR THE DIVISION OF SYSTEMS SAFETY, l.S. NUCLEAR REGLLATORY COAMISSION
\end{abstract}

J. P. Sanders, Manager

Man:sioript Completed - January 3, 1977

Date i ublished - January 1977

Prepared for the

U.S. Nuclear Regulatory Commission Office of Nuclear Reactor Regulation Uncer Interagency Agreesent ERDA 40-54 1-75

Prepared by the

OAK RIDGE NATIONAL LABORATORY

Oak Ridge, Tennessee 37830

operaced by

INION CARBIDE CORPORATION

for the

ENERGY RESEARCH AND DEVELOPHENT ADMINISTRATION

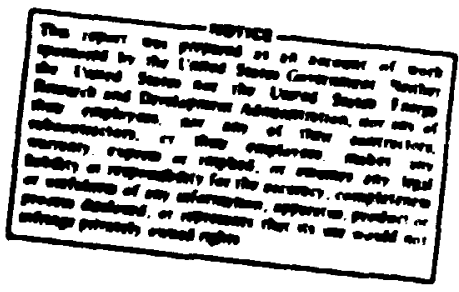


4. CCCA - A COUPLED CONDUCTION-CONVECTION MODEL FOR CORE

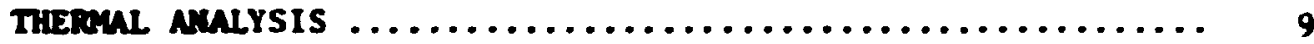

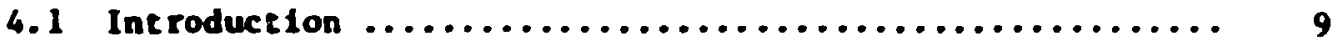

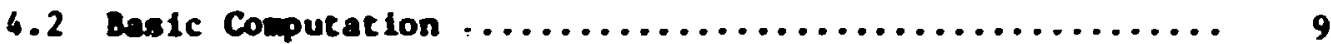

4.3 Relationship to Other Codes ..................... 9

4.4 Documentation of Code $\ldots \ldots \ldots \ldots \ldots \ldots \ldots \ldots \ldots \ldots \ldots, 10$

4.5 Example of Use ............................... 10

5. FLODIS: A COAPUTER MODEL TO DETERAINE THE FLON DISTRIBUTION NTD THETML RESPONSE OF THE FORT ST. VRAIN REACTOR ........ 11

6. HEXEREI 2 CODE DEVELOPAENT ....................... 14

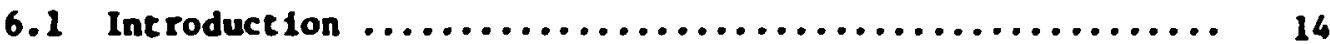

6.2 Relationship to Other Codes .................... 17

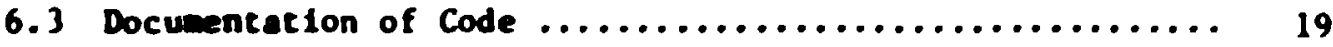

6.4 Exalp les of HEXEREI 2 Analysis of HTCR .............. 21

6.4.1 DADA2 analysis ........................ 21

6.4 .2 Analysis of $40 \%$ poiver reactor trip $\ldots \ldots \ldots \ldots \ldots . . .21$

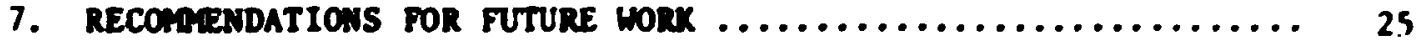

7.1 Review of Fort St. Vrain Operation $\ldots \ldots \ldots \ldots \ldots \ldots \ldots .25$

7.2 Review of Large HTGR Performance .................. 27

7.3 Computational Techniques Avallable from Ocher Codes ..... 29

7.4 Conclusions $\ldots \ldots \ldots \ldots \ldots \ldots \ldots \ldots \ldots \ldots \ldots \ldots \ldots \ldots \ldots \ldots \ldots \ldots$

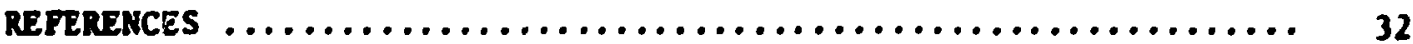


PREvious Photess Matis IN THIS SERIES

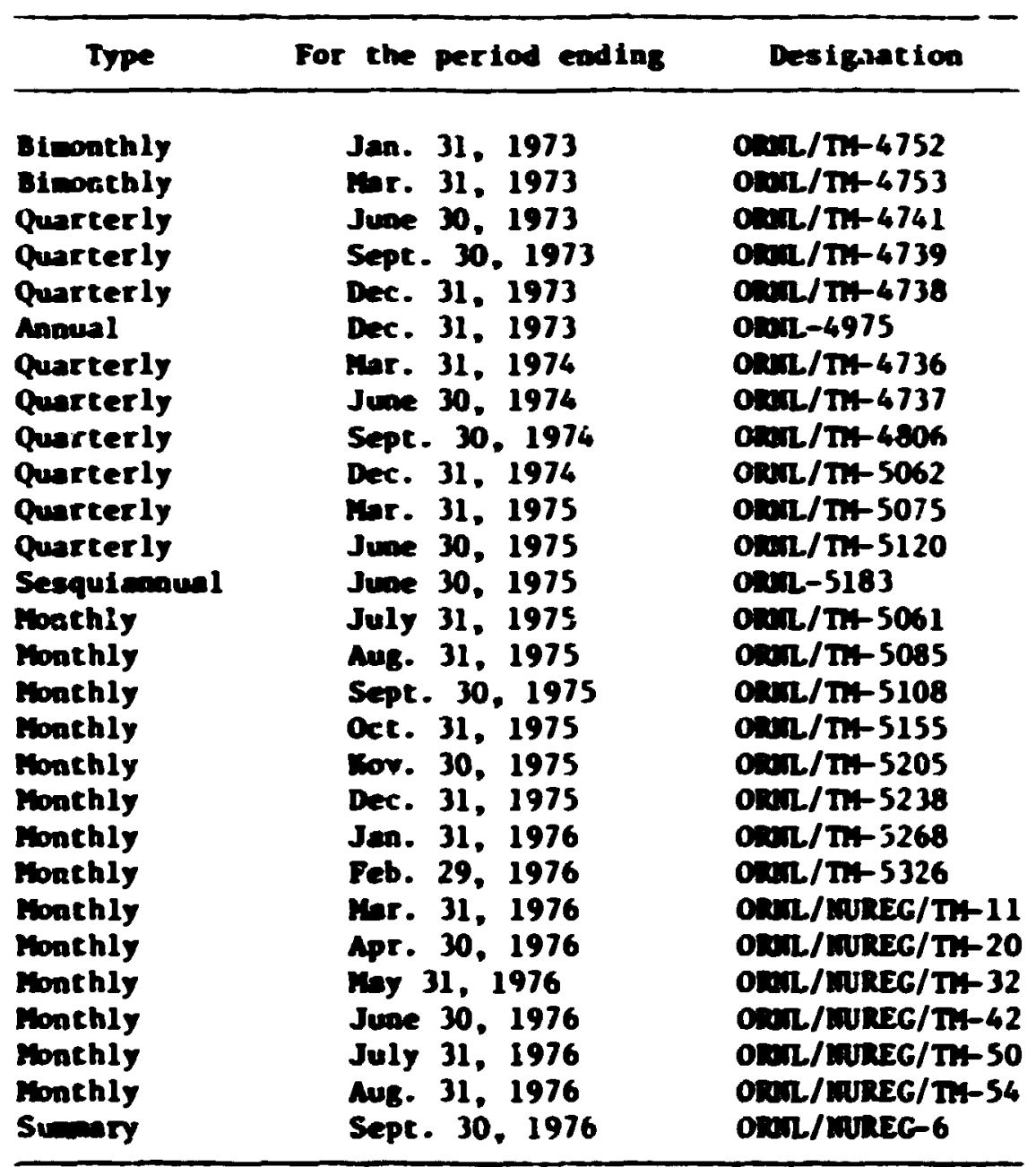


1. J. P. Sanders, U. D. Turwer, S. J. Ball, R. M. DeVault, C. E. Giles, and D. D. Paul. Evaluation of Thermal Response in Fort St. Vrain reactor Primary System to a Design-Basis Depressurization Accident Followed by Cooling with Two Pelton theel Drives operating at 700 ' rpm, Oxu/TIt5140 (Decenber 1975).

2. R. L. Reid and J. P. Sanders, InCREs: A Computer Code for the Rate of Air Ingress into an HTCR Follaving a Design-Basis Depressurization siecident, 0ral/nt5144 (Decenber 1975).

3. S. K. Iskander, C. H. Collins, and J. P. Sanders, Inelastic Analysis of Two Plates Under Deformation Dependent Loads, 0ren/TH-5206 (February 1976).

4. J. R. Tallackson, The Thermal Transport Properties of Helium, HeliumAir Nixtures, Water, and Tubing Steel Used in the CACHE Prograr to Compute HTCR Alariliary Heat Exchanger Performance, ONm/Th-4931 (February 1976).

5. J. R. Tallackson, CACHE - An Extended BASIC Progrom which Computes the Performance of Sheli and Tube Heat Exchanisers, ORul/nt-4952 (March 1976).

6. C. E. Giles, R. M. DeVaulc, H. V. Turner, and B. R. Becker, HEXEREI A rultichanel Heat Conduction Convection Cole for Use in Transient Thermal Hydroulic Analyeis of High-Temperature Gas-Cocled Reactors, K/CSD/TI-1 (May 1976).

7. D. D. Paul, FLODIS: A Computer Model to Determine the Flaw Distribution and thermal Respcrse of the Fort St. Vrain Reactor, ORnL/TM-5365 (June 1976).

8. R. L. Thaley and J. P. Sanders, Thermal Response of Core and Centralcavity Components of a High-Temperature Gas-Cooled Reactor in the Absence of Forced Convection Coolant Flow, ORN/Tht5354 (Septenber 1976).

9. D. D. Paul, Depressurization Accident Anainses for the Fort St. Vrain Reactor, ORNL/NUREC/MH-58 (December 1976).

10. I. I. Siman-Tov and H. D. Turner, HEATUP - A Computer Progron for the Thermal Analifsis of a LOFC ACcident in an HTCR, ORNL/CSD/TM-15 (Novenber 1976).

11. W. D. Turner, HEATINGS - An IBM 360 Heat Conduction Program, ORNL/CSD/ Th-15 (In publical ... 
12. W. D. Turner and J. P. Sanders, CCCX - A Single-Channel, Coupled,

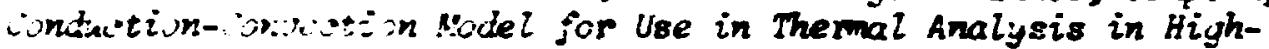

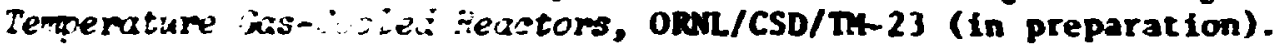

13. G. E. Giles, W. D. Turner, K. K. Childs, R. M. DeVault, and B. R. Becker, HEIEREII: Co-iter Progrom for the Transient Themal HydrauIic inalisis of Hinh-Terterature Sas-Cooied Reactors, $\mathrm{K} / \mathrm{CSD} / \mathrm{Mr}-3$ (in preparation). 


\section{FORENORD}

This sumary report replaces the fifteench in a series of wonchly reports describing technical assistance provided to the Diviston of Systers Safety of the LSNRC. It sumarizes the accomlishments made during FY 1976 (July 1, 1975 te June 30, 1976) and the Lansition quarter (July 1, 1976 to September 30, 1976) and thereby fultiils the requirements for an annual report covering chis period. A complete list of all the regular progress reports and annual sumaries, plus those copical reports completed during the sumary perfod, is given at the front of this report. This work was initiated in November 1972 at the request of the GasCooled Reactors Branch of the Directorate of Licensing of the ISAEC and consists in supplying technical assistance and making analyses in support of licensing procedures for high-temperature gas-cooled reactors (HTGRs). The work coutinued under this branch during the change from the USAEC to the USNRC. In July 1975, the management of the assistance contract was transferred to the Division of Systems Safety of the Office of Nuclear Reactor Regulation of the USNRC, and the work continued under this division through FY 1976 and the current transition quarter. Because of the elimination of attempts to comercialize the HTGR plant, beginning with the cancellation of the Sumit Power Station in October 1975, support of this effort has been significantly reduced, and it will be cerminated at the end of the transition quarter. This report, therefore, represents the final report in this series. 
SUTARY

\section{Introduction}

This is a sumary report describing technical assistance provided to the Division of Systens Safety of the USNRC during FY 1976 plus the transition quarter; it also represents the final wonthly report required for the work. This presentation reviews briefly the analytical methods that were developed during the course of the task. The features of these analytical wethods are compared with methods used to perform sinflar analyses, and examples of the use of these wethods are cited.

\section{HEATUP - A Conquter Code for the Thermal Analysis of an LOFC Accident in an HTGR}

The HEATUP code was written to determine the temperatures developed in the core of a high-temerature gas-cooled reactor (HTGR) following a loss-of-forced-cooling (LOFC) accident colnciding with a reactor trip. No convective cransport of heat is represented in the calculation. Through the use of the total facilities built into the code, it is possible to determine the cemperatures developed in the various refueling regions and relace them to the fuel age (or exposure co irradiation).

\section{HEATINGS - An IBM 360 Heat-Conduction Code}

HEATING5 is the most recent modification of a general-purpose heat conduction code developed at Oak Ridge National Laboratory (ORNL). It formed the basis of several other specialized codes developed for this task. Modif Ications were ade or features were added to HEATING5 to serve the needs of these specialized codes. To reflect this work, it is cited in this sumary report. 


\section{- CCCM - A Coupled Conduction-Convection Model for Core Thermal Analysis}

The CCCM is a particular model developed using the tacility of the HEATING5 cude. It limits the geometry options to a two- or three-dimensional cylindrical coordinate system and then incorporates a coolant channel model along the z-axis. This coupled convection-conduct ion model can represent either a nominal or "hot" cooiant channel in the HTGR core. With the use of the three-dimensional R-? option, the effect of blocked coolant channels in the vicinity of the open coolant channel can be studied.

5. FLODIS - A Computer Model to Determine the Flow Distribution and Therwal Response of the Fort St. Vrain Reactor

To make use of the single-channel analysis provided by CCCM, it was recessary to specify the 三low of coolant in the channel. During a $t$ ransient situation in an HTGR core, the distribution of coolant flow among the various regions will depend upon the total amount of coolant flow and the cemperatures in the core. The FLODIS code was written to provide this information. It began as a relatively simple, multichannel model with only one solid node represented per channel. When it was found that convection transport of heat down the channel was an important effect, the number of axial nodes was easily expanded to a maximum number of $1 \mathrm{CO}$ per channel. When the effect of axial conduction was questioned, this feature was added to the computation. The final refinement was to represent the conduction between nodal points in planes perpendicular to the coolant flow. This was done using a rectangular mesh rather than the hexagonal mesh of stmilar codes. By placing four wesh points within each refueling region, intraregional effects could be represented. The configuration represented by Findis was specifically the geometry of the Fort St. Vrain core; FLODIS is not a general-purpose calculation. 


\section{HEXEREI2 Code Development}

While ILODIS was developed to provide a quick response to specific questions about the Fort St. Vrain review procedure, a wre general altichannel, coupled conduction-convection progran, HEXEREI2, was developed for the designs of large uTCRs. The core nodel, wich was originally called HEXEREI. W111 generate cie representation of the HTGR core for a range of design operacing powers from the stuple designation of overall core characteristics. The conductive relationships are expressed in terms of a hexagonal grid and rely on the numerical techniques represented by the subprograns of HFATIMGS. The accuracy of this representation of both the conductive and convective heat transfer characteristics of the core was evaluated by executing simplified problens whose solutions could be compared with analytical or nuerical results from proven methods. HEXEREI was coupied with a group of subrout ines representing the performance ciaracteristics of the core auxiliary heat exchanger (CAHE) and the circulator of the core auxiliary cooling system (Cacs) plus the subrout ines required co determine the distribution of coolant flow in the core, and this cotal code is called HEXEREI2. Although the existence of the CACS component wodels akes the HEXEREI2 code directly applicable to curtent large comercial HTGR designs, it can be adapted for use in evaluating transients for the primary system of the Fort St. Vrain reactor. 


\section{IETRODUCTION}

J. P. Sanders

At the beginning of FY 1976, the assistance contract for the highcemperature gas-cooled reactor (HTCR) safety studies with che office of Nuclear Reactor Regulation, USNRC, was transferred for adainistrative guidance from the Division of Reactor Licensing to the Division of Technical Review (DTR). After the transfer, sone of the previous work in the development of general analytical techniques was continued, and some of the existing studies vere completed; however, the general scope and direction of the work was altered to neet the needs of the DTR.

Later, In December 1975, the Office of Huclear Reactor Regulation was extensively reorganized, and the function of the DTR was assigned to the Division of Systens Safety (DSS). The work continued under the guidance of personnel of that division through the resainder of the fiscal year plus the transition quarter.

Changes in the licensing status of HTGR plants also affected the course of the work during this reporting period. At the beginning of the period, preliminary safecy analysis reports (PSARs) and requests for construction permits had been subaitted for two plants - the Sumit Power Station' of the Delmarva Power and Light Company (DP\&L) and the Fulcon Generating Station ${ }^{2}$ of the Philadelphia Electric Company (PEC). In addition, various licensing topical reports (LTRs) were under review, and a generic PSAR, 3 designated GASSAR-6, had been subatted. The Fort St. vrain plant was in the final stages of license review before going to power. At the same time, there were indicatjons that reques:s for construction permits would soon be submitced for several more HTCR units.

The overall picture changed drastically when the General Atomic Company (GAC) announced in October 1975 that the contract with DP\&L for the Sumit Power Station would be cerminated. After this announcement, work directed toward the licensing of tive fulton Generating Station was also suspended, and plans for the other HTGR plants were discontinued or indefinitely postponed. The remaining licensing work related to the Fort St. Vrain plant and to the review of GASSAR-6 and the LTRs. 
These changes in progran objectives plus the changes in progra: guidance due to the reozganization of the of $f$ ice of Nuclear Reactor Regulation have resulted in a continuing restructuring of the tasks reported in this sumary. As a final consequence of the decreasing need for technical support, it was announced that the assistance contract would be terminated at the end of the transition quarter.

The final work under this progran consisted ainly in an ef fort to complete and document the computational methods deveioped through the conrse of the entire study. This final report briefly sumarizes those computational methods and cites the copical reports that describe thea ta detail. Where applicable, examples of the use of these methods are given as fllustrative of the work performed during the reporting period. 
2. HEATUP - A COAPUTER CODE FOR THE THEROAL AMALYSIS OF AN LOFC ACCIDENT IN AN HTGR

W. D. Turner

\subsection{Introduction}

In the safety evaluation of the transient response of active cores of HTCRs under abnormal operating conditions, it is important to obtain the transient temperature distribution following a loss-of-forced-cooifing (LOFC) accident that is recognized as cne that would lead to a axima hypothetical fission-oroduct release (RAFPR). Thus, the computer code HEATUP was designed specifically to study the problem of the transient accumulation of heat in the active core of an HTGR for use in the analysis of an RHFPR arising from a total LOFC accident and simultaneous reactor trip. It calculates the aximu cemperature as a function of tine as well as the fractions of active core where temperatures exceed specified values as a function of the age of the fuel in the various refueling regions. It was used in the theraal analysis of LOFC accidents involving both the Sumit Power Station and the Fulton Generating Station.

The HEATUP code, a modification of the general, wultdimensional computer progran HEATIMGS, was designed for the theraal analysis of an LOFC accident in an HTGR. The code is designed to calculate the transient temperature distribution for two-dinensional R2 and threedimensional R日Z wodels of the active core of an HTGR after an LOFC accident. The calculations assume there is no coolant flow in the active core during the transient. The thermal properties may be dependent on temperature and position. The effective theral conductivity may also be anisotropic in the active core, and this function is calculated using input data on the fuel, graphite, and coolant. The power in the reactor is a function of the radial and axial power-peaking factors as well as time. HEATUP is designed to calculate the percentages of the active core where temperatures exceed three criterla, which are a function of the time the fuel has been in the reactor (or the fusl age). If the respective temperature criteria for each age group represent the same fuel condition, then the code is capable of computing the cotal percentage 
of active core where the cemperature exceeds the cricerion describing the sane condition of fuel in all age groups.

\subsection{Basic Computation}

The user's manual for the HEATtP code was completed during this reporting period. It includes (1) a description of the basic problem; (2) a revieu of results related to the chofce of theral properties, boundary conditions, and initial conditions; (3) a full description of che three-dimensional R日Z model and a linted one of the two-dimersional R2 nodel; (4) the special computations that were added to hEATInG5 in che development of HSATUP; (5) input preparacion; and (6) a sample problea conststing of the three-dinensional nodel of a postulated Lorc accident for the Fulton Cenerating Station.

\subsection{Relationship to Ocher Codes}

The computational wethods used in the HEATUP code are the same as those used in the HEATImGs code.

HEATUP is similar to the coRCON code" of GAC, but hEATUP permits a wore detalled description of the HTCR core. HEATUP allows both twodimensional $\mathrm{RZ}$ and three-dimensional $\mathrm{R} \theta Z$ wodels, whereas CORCON allows only two-dimenstonal RZ models. Also, HEATUP, as compared to concon, describes the fuel condition in wore detail. CoRcow ytelds tre fraction of core above specifled teaperatures as a function of tine, whereas HEATUP can depict in addition the fuel condicion as a function of lifetime in the active core.

\subsection{Documentation of Code}

The report5 documenting the HEATUP code has been reviewed and should b* distributed by the end of November 1976 .

The PORTRAN source deck and related sample problems will be sent to the DSS for further distribution. 


\subsection{Exaple of Use}

The HEATUP code is designed to malyze the specific problea of the trassient accumalation of heat in the active core of an ITCR arising from a total Lof accident and simucaneous reactor trip. Specific examples of its use are described in the aEATUP report. 5 


\section{HEATIMGS - AN IBH 360 HEAT-CONDUCTION CODE}

H. D. Turner

\subsection{Introduction}

HEATIMG5, a modification of the generalized heat-conduction code HEATIMG3, is designed to solve sceady-state and/or cransient heatconduction problems in one-. two-, or three-dimensional Cartesian or cyl indrical coordinaces or oae-dinensional spherical coordinates. The chernal conductivity, density, ard specific heat ay be both spatially and temperature-dependent. The thereal conductivity may be anisotropic. Materials ay undergo a change of phase. Heac-generation rates may be dependent on tine, cemperacure, and position, and boundary cenperacures ay be dependent on tine. The boundary conditions, which may be surfaceto-boundary or surface-to-surface, my be fixed cemperatures or any combination of prescribed heat flux, forced convertion, natural convection, and radiation. These boundary-condition paraneters may be dependent on tine and/or temperacure. The nesh spacing can be variable along each axis. The code is designed to allow a maximu of 100 regions, 50 materials, and 50 boundary conditions. The maximu nuber of lateice points can be easily adjusted to fit the problem and the available computer eemory. The requirements on an IM 360 machine range from approximately 250,000 bytes for one lattice point to $1,256,000$ bytes for 6000 lattice points.

\subsection{Basic Computation}

The development of the HEATIMGS code was partially funded by the Office of Nuclear Reactor Regulation of the U.S. Nuclear Regulatory Comassion. Some work on developient of the code was continued during this reporting period, but wost of the work was directed toward documentation of the code. 


\section{I Relationship to Ucher Codes}

The point suicessive-overrelaxation-iterative method and a modification of the "Aicken : 2 extrapolation process" are used to solve the finitedifference equations, which approxinate the partial differential equations f.jr a steady-state problen.

The transient problem ay be solved using any one of several finitedifference methods. These include (1) an implicit technique that can range from Crank-Nicholson to the classical inplicit procedure, (2) an explicit mechod that is stable for a time step of any size, and (3) the classical explicit procedure that involves the first forward cire difference. The solution of the system of equations arising fron the implicit technique is acconplished by point successive-overtelazation iteration and includes procedures to estiance the optinan acceleration parameter. Transient problems involving aterials with change-of-phase capability cannot be solved using the implicit cechnique with this version of HEATING5.

HEATING5 writes a data set that is used by the HEATPLOT computer code to generate plots containing isotherns and temperature profiles. HEATPLOT is a general plotting program that allows the user considerable flexibility in generating various plots of results from the heat-transfer calculations.

The HEATIMCS code is similar to many other general heat-transfer codes. Some of the other codes and the laboratories where they were witten are: TAC2D and TAC3D from General Atonic Company; TRUAP from Lawtence Livernore Laboratories; SAHAR from Sandia Laboratories, and TAP-B and TRACK from Westinghouse Astronuclear Laboratory. Host of the general heat-transfer codes are similar in nature. Some features of HEATIMGS that my not be avillable in other general heat-transfer codes are (i) a nodal point generator; (2) independent solution techniques for transient and steady-state problems; (3) several techniques, both explicit and implicit, for solving transient problems; (4) a variety of boundary conditiuns; (5) nonlinear problems to include the source cerm; and (5) an output map of the temperature distribution. Features found in some of the codes mentioned above that are not avallable in HEATIMGS are (1) the ability to model problems other than those described in Cartesian, cylindrical, and spherical coordinate systems; (2) coupled mass-flow calculations; (3) material property 
libraries; (4) free-fo:- input; and (5) input data specifically designed to facilitate paranetric studies.

\subsection{Docuentation of Code}

The report" documenting the HEATIWGS code, which is in the final stages of preparation, should be ready for publication in late 1976.

The FORTRAx source deck and related sample problens will be placed in the Argonne Code Center.

\subsection{Exarple of Use}

The HEATIMGS computer code my be used for a wide variety of diffusion-type probleas that can be modeled in Cartesian, cylindrical, or spherical coordinates. 


\section{CCCM - A COLPLED COLDUCTION-CONECTION}

MODEL FOR CORE THERMI AWLYSIS

W. D. Turner

\subsection{Introduction}

The coupled conduction-convection model (CCCY) conputer code, a modification of the general heat-transfer code HEATINCS, has been especially modiffed to provide localized cemperatures in the fuel, graphite, and coolant channel of an HTCR during noral operation as well as during accident conditions involving reduced flow and loss of forced cooling. It is designed to calculate the steady-state and transient temperature distributions for cwo-dimensional R2 and three-dimensional R6Z models coupled to a single, one-dimensional, axial coolant channel. In addition to the input data required by HEAIING5, CCCA requites the following information about the coolant: inlet temperature, mass velocity, composition, and pressure. It also requires certain information concerning the coolant channel for the HTGR in question.

\subsection{Basic Coeputation}

A few winor refinements were made to CCCM during the reporting period. During the first quarter, the calculations concerning the evaluation of the thermal response in the Fort St. Vrain Reactor arising from a design-basis depressurization acsident (DBDA) followed by cooling with two Pelcon wheel drives were completed. A number of cases were studied using the ccar code, and the results are presented in ORNL/MM-5140 (Ref. 7).

\subsection{Relat ionship to Other Codes}

The CCCM code is a modification of the HEATINGS computer code and, as such, uses the sase numerical techniques for the heat-conduction analysis. The convection calculations are based on a one-dimensional axial model, where the coolant temperature is based on the mass velocity, the upstream temperature, and the heat flow between the solid and coolant. The heat 
flow between the solid and coolant is a function of the flow regime and the channel configuration.

The cccm code requires input information concerning the coolant, which can be obcained from codes such as flodis.

\subsection{Documentation of Code}

The $\mathrm{CCCM}$ code has been documented in a report ${ }^{3}$ current ly in publicacion. The FORTRAN source deck and related sample prublems will be cransmitced co DSS for further discribusion.

\subsection{Exanple of Use}

The CCCH computer code can be used to study localized remperatures within the core of an HTCR for a variety of situations, provided accurate inlet coolant information is available. Some examples of situations where it can be used are: normal operaticn; scram of the reaccor; accidents such as design-basis depressurization and loss of forced cooling; blocked coolant channels: variations in power, inlet coolant temperature, and inlet mass velocity; and closed orifices. 
5. FLODIS - A COAPUTER MODEL TO DETERHINE THE FLON DISTRIBLTION AN THERML RESPOUSE

OF THE FORT ST. VAIN REACTOR

D. D. Paul

In February 1975, the Huclear Regulatory Conisstion asked Oak Ridge National Laboratory to perform an independent analysis of the thermal response of the Fort St. Vrain reaztor core and primary coolant systea following a postulaced design-basis depressurization accident (DBDA). The FLODIS code was developed in response to that request and has since been revised several cimes.

FLODIS is a combined fluid-flow and heat-transfer analysis calculation writcea specifically for the core of the Fort St. Vrain reactor. It is a lumped-node representation of the 37 refueling regions in the active core, the side reflector blocks, and the prestressed concrete reactor vessel (PCRV). Features of the FLoDIS code Include models to represent (1) interregional conduction of heat, (2) both forced and natural convection flows, (3) Intraregional distribution of coolant flow, and (4) the PCRV-liner cooling system. The calculation uses the specif ied operating conditions for the reactor at pouer to deternine appropriate loss coefficients for the variable orifices in each refueling region. Flow distributions following reactor trip and a reduction in coolant pressure and flow are detarmined assuaing that the orifice coefficients realin constant. Iterative techniques are used to deternine the distribution of coolant flow as a functior of tive during the cransient.

The latest verston of FLODIS uses a rectangular grid to model the entire core of the Fort St. Vrain reactor. A typical refueling region is approxinated by four rectangular mesh spaces. Heat is allowed to flow between all adjacent wesh spaces. Note that all current models used to represent multiple regions in HTGR cores (HEXEREI, ORECA, RCCA) are based on hexagonal grid spacing. Results from the rectangular nodel will provide a valuable check of the shape factors used in models with hexagonal grid spacing.

The flow distribution codel has been expanded to include both forced and natural convection flow. Concurtent with this improvement, the flow is allowed to redistribute ltself within a refueling legton according to 
the finer mesh spacing. Intraregional distribution of coolant flow ts not represented by HEXEREI, ORECA, or RECA. This ef fect is important during some postulated accident sequences there there are large temperature gradients across 3 refueling region.

finally, the core wolel has been expanded to include the side reflector, gas aunulus, and PCRV-liner cooling system. These inprovements were necessary to decernine the capability of the PCRV cooling system to remoye af terheat during some postulated accident sequences.

Figure 5.1 shows the results of a DADA analysis using the FWDIS code. Also shown on the sane graph are results reported by CAC using their RECA code.

The FloDIs code was docuseated in a topical report' ${ }^{9}$ issued in June 1976. Subsequent codifications of the code are described in a wore recent docunent, 10 which also presents the results of analyses of certain specified DADAs for the Fort St. Vrain reactor.

A copy of the FORTRAN symbolic program plus a set of sample input wis prepared for subaission to the Argone code Center. The symbolic language used is compatible with the IBM FORTRW IV, level H compiler, release 21.6 . A saaple set of the job control language (JCL) for the MASP system on the IEM 360, codel 91 was also supplied. 


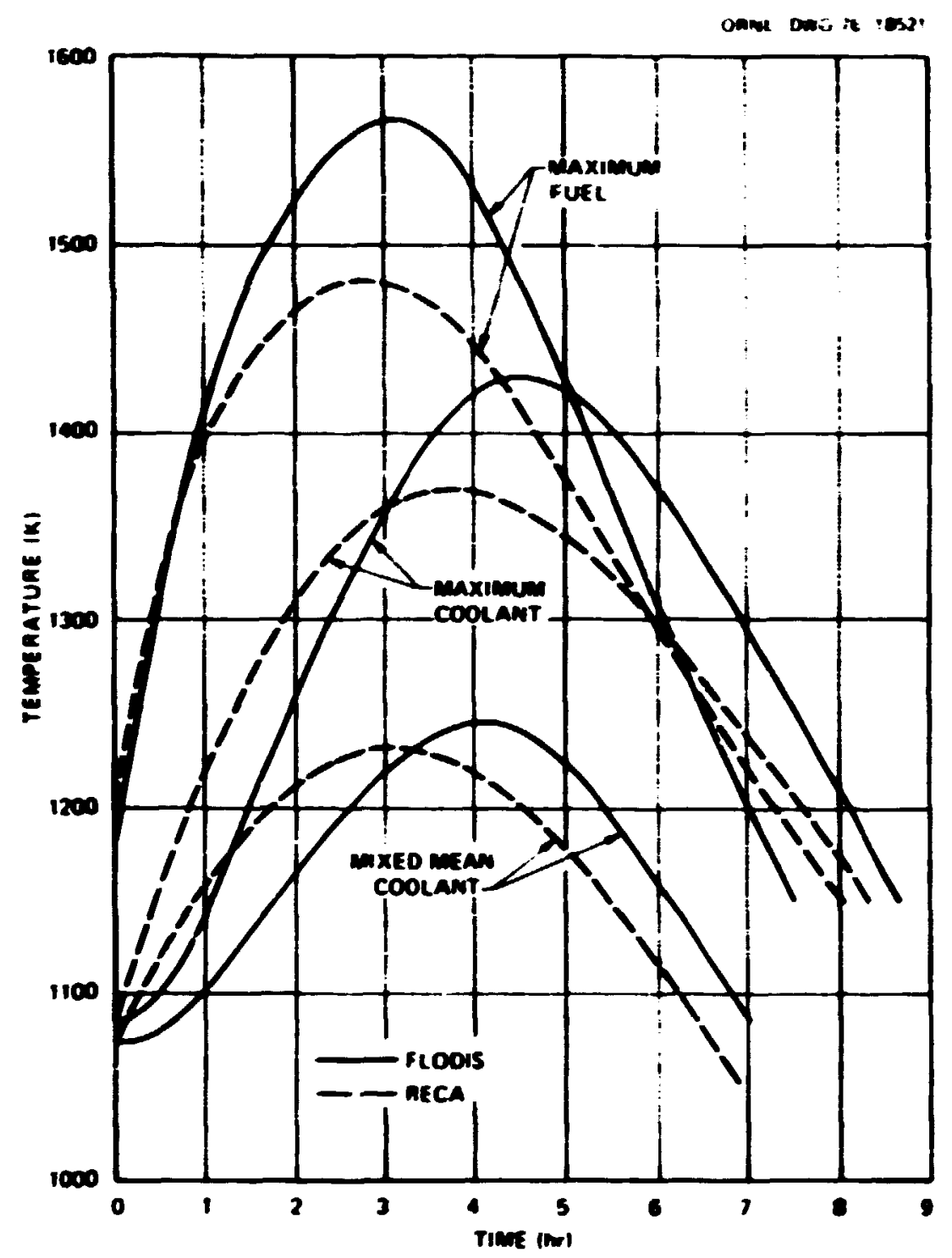

Fig. 5.1. Comparieon of FlODIs and nech temperatures during a postulated Fort St. Vrain DSDA with 7000 rpe circulator speed. 
6. HEXEREI2 CODE DEVELOPMENT

G. E. Giles K. W. Childs

\subsection{Introduction}

HEXEREI 2 is a three-dimensional, coupled, conduction-convection heattransfer and wulcichanel fluid dynamic analysis computer code for both steady-state and transient problems. The program was developed to provide thermal fluid dynamic analysis of high-temperature gas-cooled reactors (HTCRs) to satisfy licensing procedures for the Nuclear Regulatory Comaission (NRC).

The development of HEXEREI 2 was comisstoned by the ARC to provide an analytical capability that was independent of those used by the reactor vendor and was not available at Oak Ridge or other sites. The General Atomic Company (GAC) is tho only active HTGR vendor in the United States, and its designs represent a departure from both those of $t^{-}$. European gascooled reactors and the normal light-water reactors. The development of HEXEREI 2 was restricted to the current comercial HTCR design of GAC and was initiated in June 1974, with the goal of producing a code with safety analysis capability. Improvements were possfble on GAC's RECA technique, ${ }^{11}$ since the project was starting with a previously developed code ${ }^{6}$ (HEATINC5) and the developers had the benefit of recognizing the deficienctes of existing codes. Another major goal was to develop a code that would be compatible with other computer systems, thus allowing NRC personnel to use it on other systems to develop expertise and confidence in the safety analysis of HTGRs.

The gross model of the HTGR is a right circular cylinder with fuel of nonuniform characteristics dispersed regularly throughout an inner region (a right circular cylinder shorter and of smaller radius than the model). Coolant flow is distributed in a large number of axial coolant channels extending from the top to the bottom of the core model. Thus, heat transfer in the HTCR core involves both three-dimensional weat conduct ion and convection to the axially fluwing coolant in the coolant channels. When the coolant flow is large, convective heat transfer is the signif icant process and will tend to produce temieratures that are uniform in the axial plane 
in each refueling region. This is due to (1) the unifornity of heat generation in the refueling resions; (2) the uniform distribution of a large number of saall coulant channels, which will have approximately the same coolant anss flow; and (3) the high mass flow, which tends to reduce the theral gradients in the solid in the axial plane and control the heat transfer In the axial direction.

As the aass flow changes, the relative resistance to flow in each channel changes due to buoyancy and to losses from friction, acceleration, expansion, and contraction. The mas flow through che core any redistribute itself asong the coolant channels, since the change in resistance is not unifore throughout the core. Intetal temperature, ans flow, and differences in orifice settings contribute to the nonunifornity of change in resistance. If the flow is reduced to a value near zero, the buoyant forces produced in the hot channel could cause stagnation and perhaps upward flow in the channel (reverse flow). Also, when the flow 18 substantially reduced, heat conduction across the core becomes more important. When the net flow through the core is zero, natural convection loops can develop in the core and, over long periods, will redistribute the heat :ntil the temperatures are uniform throughout the core. During an accident translent, the coolant flow any change from full flow to zero or any intermediace level. Durins full flow, the conductive heat transfer is very saall relative to the convective heat transfer. As the flow decreases, conductive heat transfer becones wore important. Also, reversed (upward) flow becomes possible as the flow decrenses. Thus, the relative significance of the physical effects ay change with tine during the transient. Accurate heat conduction, heat convection, and fluid dynamic wodels for all possible heat-transfer paths that ay occur during a transient are required for any code that is to be utilized for MrGR accident analysis. Such an analysis technique, dealing with (1) the core, (2) the upper, lower, and side reflectors, and (3) the upper and lower plenums, is incuded in the HEXEREI code.

In the large HTGR design, helium normally flows downard through the fuel element coolant channels, the cracks around the fuel elements, the control rods, and the side reflector elements and into the lower plenum through collector ducts; then it goes up through the core auxiliary cooling 
systen (CACS) heat exchanger bundle and the CaCs circulator and froe there Into the upper plenu to return to the core.

The analysis for the cotal loop is included in HEXEREI2. HEXEREI2 contains HEXEREI merged with a package of routines (ACHERONS) that includes the eoveling for the CACS portion of the loop. Thus, HEXEREI2 has the capability of analyzing accurately the three-dimensional, heat conductionconvection problen for flows from zero to the aximu valives obtained in the closed-loop systea. The external boundary conditions for the closed systen are the vater inlet temperacure, flows into the Cacs, and circulator perforance characteristics.

:DXenEI2 can perforn the above analysis for the Fort St. Vrain HTGR as well as all HTCRs that are sinilar to the 2000- and 3000-Mu(t) GAC designs. Siace the Fort St. Vrain HTGR does not contain an independent cacs loop, efther additional input information wut be obtained or minor modifications must be ade in the progran to represent the FSV loop.

HEXEREI contains a very general matheatical package for the solution of the solid and coolant ceaperatures. The user has the option of selecting a steady-state technique, an explicit transient technique that is normally too expensive for the general three-dimensfonal problem, or a very powerful inplicit transient technique. The implicit transient technique is capable of considerably reducing the cost of a computation. However, for probles requiring very small time steps, the explicit cechnique 18 less expensive than the inplicit. The treatment of the boundary condition, material properties, and heat-generation rate is very general in HEXEREI 2 and allows the user great flexibility in wdeling. However, the hexagonalwesh generator, the coolant temperature and flow redistribution techniques, the coolant channel description, and she coolant system are somewhat 1 imited to HTGR-type problems. HEXEREI can analyze problems other than heat transfer in an HTGR, but since this development was not within the scope of the project, modifications to the code may be required.

HEXEREI2 w11 automatically generate the mesh geometry specifled by the user within some fairly broad-based constraints. A wide range of possible HTGRs is included within the mesh-generation capabilities of the code. The user can thus modify the model under analysis by changing a few simple geometric input values. 
A companion code, HEXPLT, was developed to enable the user to obtain graphic presentation of information pertinent to HTGR analysis.

\subsection{Relationship to other Codes}

During the siciety studies of HTGR designs of GAC, various ORNL computer codes have been evaluated. One of the first utilized at Oak Ridge for HTGR analysis was HEATINGS (or HEATING4, an earlier version). HEATINGS is a very general, one-, two-, or three-dimensional (either Cartesian or cylindrical coordinate systea) heat-conduction analysis tech-sque for steady-state or transient problens. General matheatical techniques, boundary conditions, and aterial properties make hEATINGS a very versatile code. However, it requires all model boundaries (external and internal) to be parallel to the coordinate axes; thus, an ITGR core would have to be modeled in Cartesian or cylindrical coordinates. It was found from experience with HEATINGS and also from GAC's code development experience that the finest Cartesian or cylindrical grid structure capable of ficting on presently available coaputers could not perform an adequate analysis due to the lumping of several refueling regions into one cell. Since the thermal properties, age of the fuel, and power are fairly uniform within the refueling regions, it would be desirable to have at least one column of nodes per refueling region. If this criterion is applifed to HEATINGS wesh generation, the refueling regions near the core center have many nodes per region. (The cylindrical mesh is discussed here to avoid having to stairstep che boundaries of the model.) This surplus of nodes is more than an annoyance, since the small spacing reduces the maximum time step that can be used in the transient analysis. The surplus also increases the computational work per time step and the core storage requirement beyond current computer capacity. HEATINGS also lacks the ability to model the flow in a multichannel system or to couple the conduction solution to the convection solution so that the temperature of the convecting fluid is a function of the heat transferred into the fluid.

HEXEREI2 was developed from HEATINGS and retained HEATING5's major structure and some of 1 ts compatible ancillary routines. 
CCOA (Ref, 8) was developed from HEATIMGS (prior to the HEXEREI2 developent) to provide the capability of analyzing the steady-state and transleat conduction in two or three dimensions coupled with convection to a single-channel, axially flowing coolant along the outer beundary of the model. The coolant temperature is modified by the heat input over the channel length. Single-channel analyses of the HTGR are thus possible with the CCCA code and have been performed extensively." Multichannel coolant flow, a wote detafled codel of the cotal core that is adaptable to present computers, and the analysis of the cacs coupled with the core are still not possible with ccch. The analytical techaique of $\mathrm{ccc}$. is sintlar to the single-average-channel representation in the TAP code ${ }^{12}$ of GAC. TAP, however, includes a representation of the primary and secondary coolant systens in its analytical cechnique.

The single-channel analyses of the ITGR core with TAP or CCCM neglect the effects of Interregtonal heat flow and the distribution coolant flow anong the axial channe!s due to high thereal gradients and low flows. These two effects becone very important during accidents involving reactor trip, loss of primary coolant pressure, or loss of primary coolant flow with restart of flow using the cacs.

While HEXEREI2 was in the early stages of development, work was started by Paul on the FLODIS code. 9 In its earliest version, FLODIS was used in confunction with $\operatorname{ccc}$ to provide bounding values for analysis of specified transients in the licence reviow for the Fort St. Vrain reactor. Since the fluid dymanic problen was a function of che solid temperatures. FLDIS ac first included a one-node representation of each refueling region. This essentially incorporated the heat storage of the graphite into the coolant temperature calculations and enabled FLODIS to perform heattransfer analyses that ov-restinated the teaperatures developed in the core.

FLODIS provided a convenient starting point for the development of the flow distribution subroutines that were used in HEXEREI2. Significant development was required to provide a set of subroutines that would interchange information with the existing HEXEREI calculations. In this manner, the pressure-loss models in HEXEREI2 proficed from FLODIS's prior development. FLODIS also provided a convenient output display, which was utilized in HEXEREI2, 
GAC uses a complex system of routines called RECA (Ref. 11) co analyze HTGR accidents. RECA uses a nodal system which, in the axial plane, consists of one node tur each refueling region and one or more nodes in the side reflector. Each node is connected (heat is allowed to flow) co each of six neighburing nodes (refuelink regions) in the same axial plane and to one node in each of the adjacent axial planes. This nodal syster provides a sufficienty detailed analysis within the capability of existing computers. RECA also provides a coupled coolent flow and temperature analysis capability for the HTGR core with a CACS. It is the code whose analyctcal capability HEXEREI 2 was designed to duplicate. However, hEXEREI2 is note Independent of computer hardware than is RECA, and the developaental vork of HEXERI2 has atceepted to improve the efficiency of the mathematical cechniques avaflable in RECA and the accuracy in sume areas of RECA's modeling, such as the cacs heat exchanger.

In order to evaluate RECA, Ball developed the OKECA code.!: The basic model used in ORECA is similar to that used in RECA and HEXEREI2, and the basic equations (fluid dynamic and heat cransfer) solved by ORECA are simiIat to those solved by HEXEREI2. ORECA makes many assumptions in the approximations, solution of equations, and modeling that permit very inexpensive (short running time) analysis. The code requires relatively small awounts of computer memory, and changes can be made fafrly easily. However, signiflcant changes in model geometry, material properties, heat generation, or toundary conditions requite coding modifications. The computational times reported ${ }^{3}$ for ORECA indicate that assumptions have been made in order to reduce the computational time. Simplifications in a very complex, three-dimensional, cranstent, nonlinear problem should be made with extreme care. There is no assurance that the assunptions in the code that appear tc work well in one set of cases (i.e., In comparison to other codes) will function correctly in another set.

\subsection{Documentation of Code}

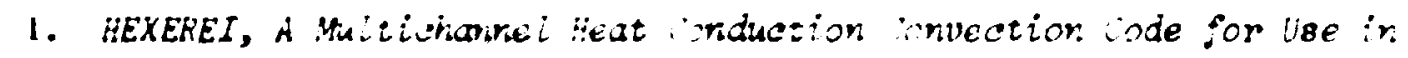

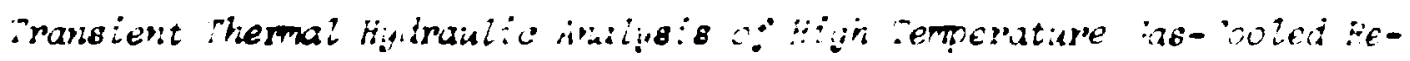
arserg, G. E. Giles, R. M. DeVault, W. D. Turner, and H. R. Becker, K/CSD/ TM-1 (Mily 1976). 
This report concains interim documentation of HEXEREI's periormance in some sample heat-transfer problems and includes comarisons with in.ligtical and/or proven computer code resules. The test isses were thosen to demonstrate HEXEREI's ferformance in each portion of an HTGR analysis (i.e.. both radial steady-state or transient conduction and convection to a c(r.lant).

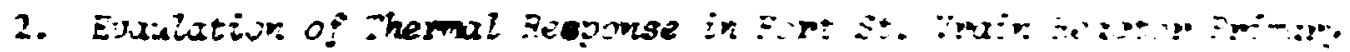

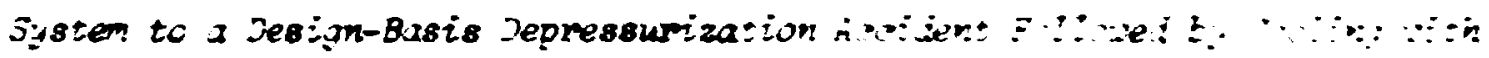

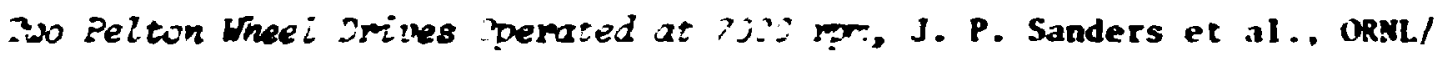
my-5140 (Decenber 1975).

The above report lacludes docunentation of ACHEROAS performance calculat lons for the Fort St. Vrain stean generator and circulator. ACHERoxS was used in a stand-alone node (wthout HEXEREI) with GAC-supplied inlet values to evaluate the perfornance of the stean gererator and circulator.

3. Letcer dated April 22, 1976, fron G. E. Giles to J. P. Sanders. Subject: "Fort St. Vraln Safety Analysis with tine Improved HEXEREI Code." (Copy transinited In a letter dated April 28, 1976, from J. P. Sanders to W. Gilbert, Project Manager, Speclal Reactors Branch, USNRC.)

The above letter contain the results of a HEXEREI analysis (stean generator and circulator not included in the model) of the behavior if the Fort St. Vrain reactor after reactor crips frow both 40 and $105 \%$ power. The analysis of the 1057 power accident (DADA2) used the same information that was used in the evaluation reported in itew 2, above. A detailed comparison of the HEXEREI solution and the GAC-supplied steady-state solution for the 407 power case was made. A discussion with caC personnel was prompted by this anolysis and ylelded some experimental Jata for the orifice pressure loss, which will be included in HEXEREI. A sumary of this inforation was Inclided in ORn/NuREG/TM-20, :Onthly Frogress Repcrt fer AFril 1376 for the HTCR Safety Studies for the rivision of Systems saf $\because$, i.S. Nuclear Pegulatory Commission.

4. HEXFREI2: Computer Progran for the Transient ihemal-Hrdrot:?: inalysis of High-Temperature Gas-Cooled :eactors, K/CSD/TM-3.

This report is the fianl report for HEXEREI 2 code development and a falrly complete user's manual modeled after the HEATINGS user's manual. Discusstons of the mathemacical techniques, modeling assumption, program 
execution op:ions, and input data are included in the document. Discussions of nine test cases and comparisons with analytical results are presented to iliustrate the code's capabilities; sone of this information is taken from K/CSD! MH-I. Also included is a series of HTCR and other analyses to aid the user in codeling his particular problen or in utilizing the full power of HEXEREI 2 .

\subsection{Exaples of HEXEREI 2 Analysis of HTGR}

The analyses listed below were perforned with the latest HEXEREI 2 code. They were done to document the kind of Information available ston HEXEREI 2 and to pernit comparison of the results with those from the RECA code of GAC. The RECA results for the DADA2 amalysis were reported in Ref . 14, and those for the 402 power trip with ccoldown using four circulators for 15 nin were reported in Ref. 15.

\subsubsection{DBDA2 analysis}

Figure 6.1 presents the comparison of results from HEXEREI 2 with those from RECA (curves marked GAC) for the maximu solid and average exit temperatures. This analysis by HEXEREI 2 includes the new orif ice pressuredrop correlation based on experinental correlations: 6 provided by GAC. HEXEREI 2 calculates an average coolant exit temperature that is consistent ly lower than that calculated by GAC throughout the transient. The reason for the exit temperature differences cannot be deternined at present. Since both analyses (HEXEREI 2 and GAC) use the sase coolant inlet conditions, HEXEREI 2 will rewove less heat from the active core. The high maximun solid temperature of HEXEREI 2 ay be due to the decreased heat removal. The agreement in the core pressute loss of the two analyses is shown in F1g - h. 2 .

\subsubsection{Analysis of $40 \%$ power reactor trip}

Figure 6.3 presents a comparison of results from HEXEREI2 and GAC for the analysis originally requested in Ref. 14. The agreement between the analyses is not as good as that shown for the DBDA2 analyses. The core pressure drop for HEXEREI 2 (not shown) was a consistent $0.28 \mathrm{kPa}(0.04 \mathrm{psi}$ ) 


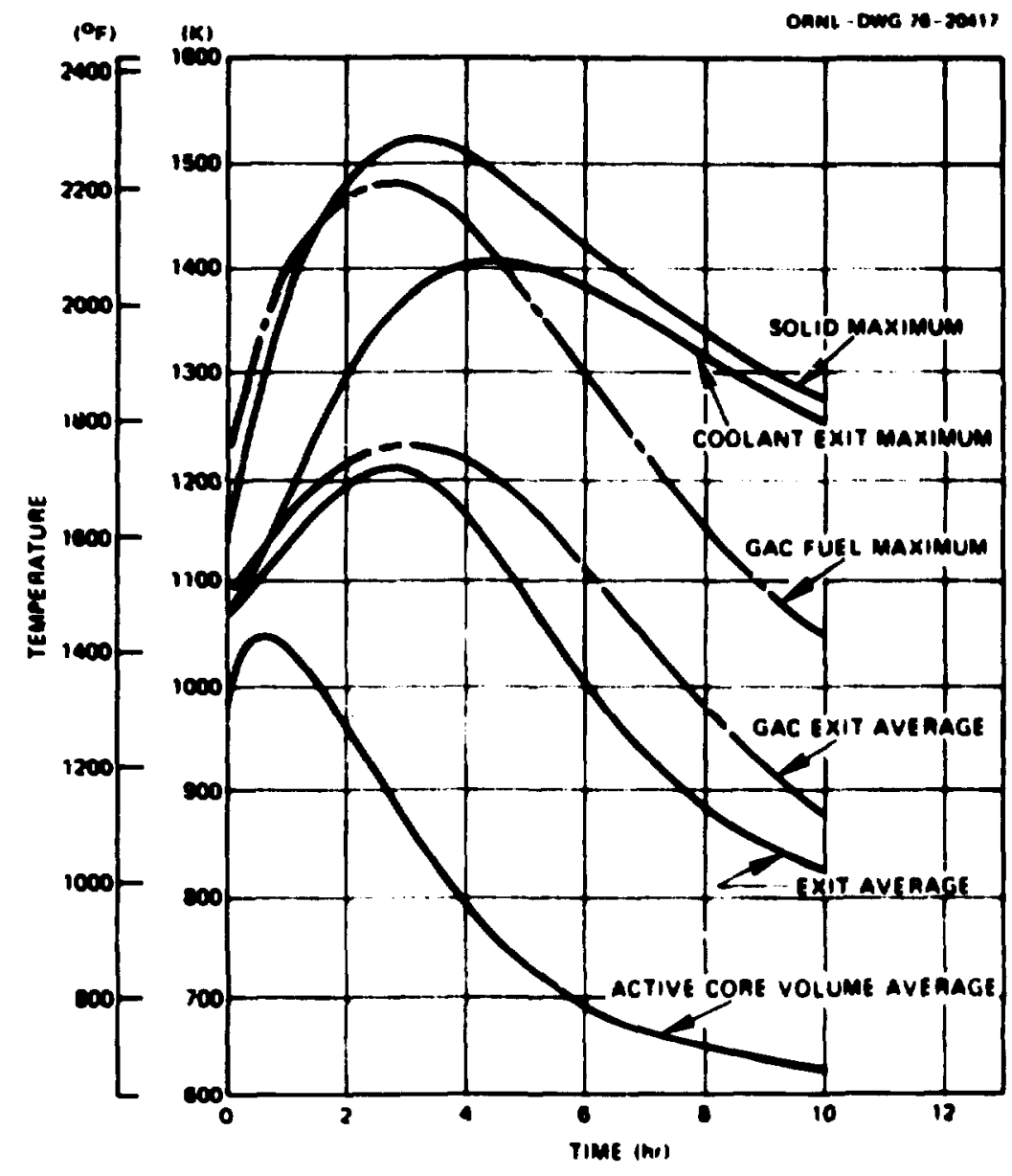

518. 6.1. Comparison of HEXEREI2 resulta for DRDA2 with reactor trip from $105 \%$ power with results provided by General Atomlc Company (GAC).

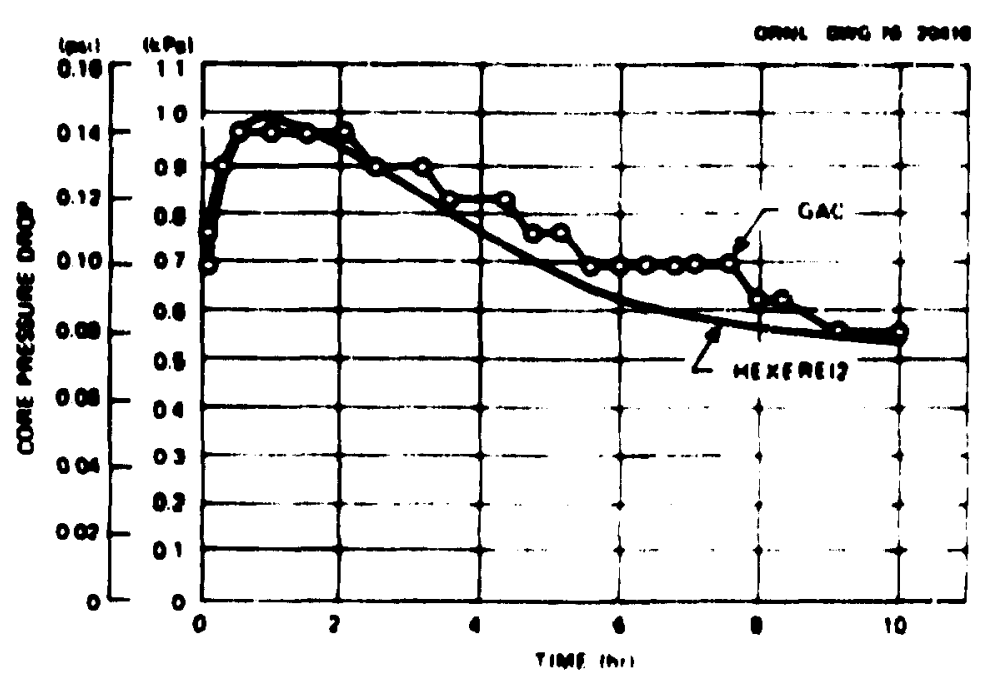

i
Hig. 6.2. Core pressure drop for HEXEREI 2 results for DBDA2 compared with values given by General Atomic Company (GAC). 


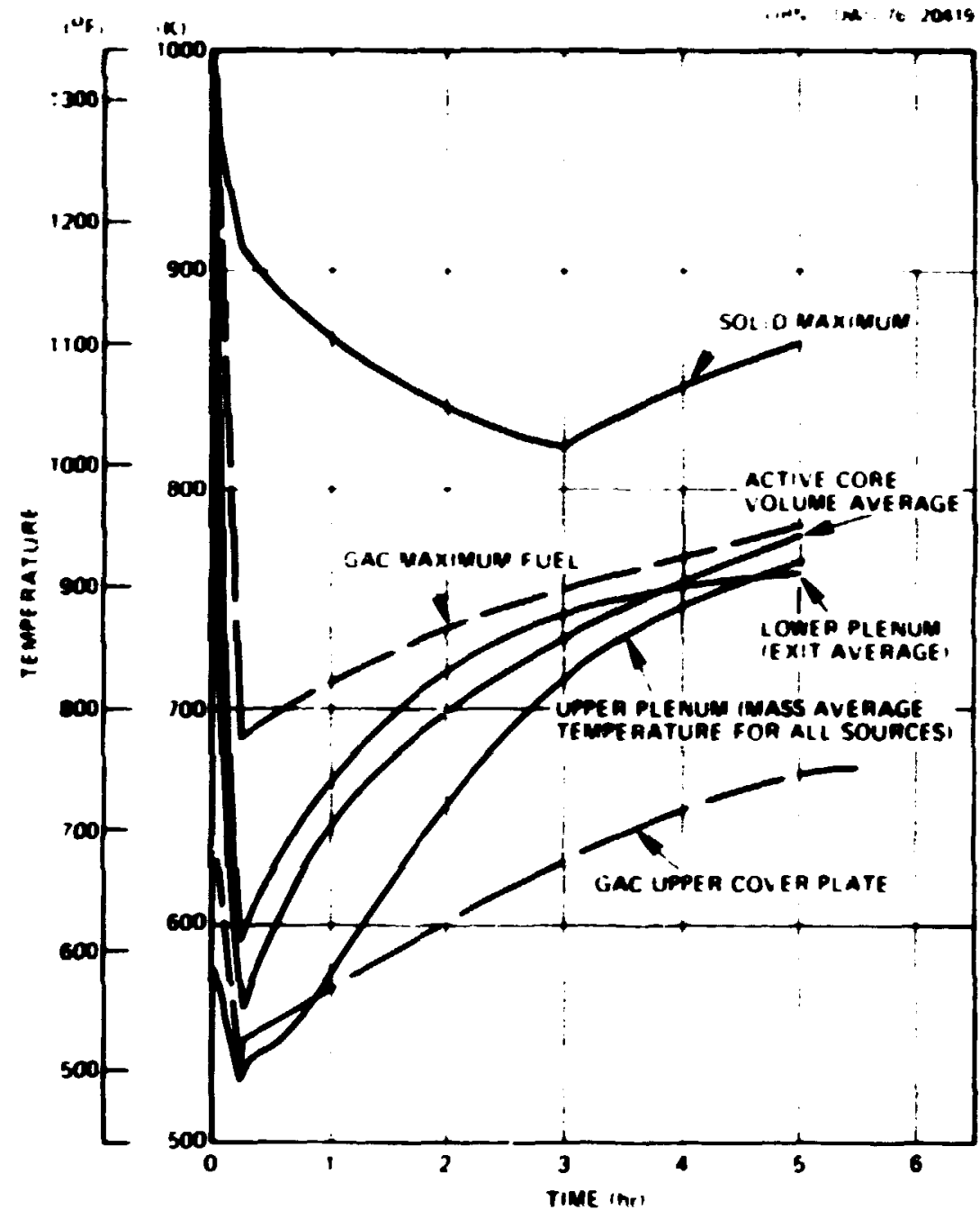

Fig. 6.3. Comparison of General Atonic Company (GAC) and hEXEREI2 results for fort St. Vrain reactor trip from 402 power with four circulators operating for 15 min (includes most recent orifice correlation coefficients from GAC).

lower than that for GAC. In the discussions with GAC in May, it was revealed that several of the coolant orifices were completely cluseu and all the flow was through cracks in the upper reflector elemen:s. Sfnce HEXEREI 2 forces all coolant exit temperatures to be equal for the steady-atate anaiysis and was able to achieve this status without closing down the orifices, some other criterion for orifice settings must have been used by GAC. Once 
the steady-state orifice-control functions used by cac are simulated in HEXEREI2. the resulting transient analysis should agree with the GAC analysis just as well as did the analyses for the DBDA2. 
i. RECONENDATIOAS FOR FUTLRE HORK

J. P. Sanders

The need for future work in the licensing of HTCR plants falls into two categories. First, and cost imediate, are the analytical needs relative to the review of the Fort St. Vrain (FSV) operation during the riseto-power sequence and the need to review or nodify the technical specifications for this reactor design. Second, there is the need to revieu the design for large comercial plants - in particular, the design described in the GASSAR-6 document ${ }^{3}$ and the related 1 icensing copical reports.

\subsection{Review of Fort St. Vrain Operacion}

It should be remembered that, at present, a single computational procedure to analyze the total detalled transient response of the core and the total prinary loop for the FSV reactor does not exist, neither wthin the ethods developed at ORNL under this task nor within the wethods disclosed by GAC. As an obvious consequence, there is no representation of the balance of plant (BOP) that is coupled with the detailed primary loop analysis. All such analyses must be done in a plecemeal manner, either by $\mathrm{CAC}$ or by use of the computational methods developed under this task.

GAC has a version of the TAP code 12 that represents the BOP plus the primary circuit of the FSV reactor; however, the core representation in this model is that of a single, nowinal channel. At zero or low flows, this single-channel model is not capable of representing redistribution of flow or flow reversals, both of which have important ramifications concerning the safety evaluat lon of abnormal transients. To obtain the required detail, CAC must use output from the TAP calculation as Input to a RECA calculation. $1 \mathrm{l}$ An obvious implication of the procedure is that there can be no feedback from the detalled RECA analysis to the TAP calculation. Since the RECA calculation represents more of the detailed flow paths in the primary circuit, the match of TAP output and RECA input is not exact. Thus, there 18 a need for a single computation 
that includes both the detall of the prinary loop and sufficient detail of the DOP to perforn a single analysis of the cransient.

In the work performed for the Office of Nuclear Reactor Regulation at onn, our efforts have been directed primarily toward "abnornal cransfents" In large HTCRs, and only in the last 12 monchs has the primary focus of our work changed to the analysis of FSV transients. For the large reactor designs, the abnoral transients cited were initiated after the loss of the alin loop cooling. Thus, our work was directed toward the analysis of the core in conjunction with the core auxiliary cooling systen (CACS). The present HEXEREI 2 code ${ }^{17}$ represents the ultimate development in analytical wethods for these transients. It is adaptable to cores of various power levels with the same general prinary circuit configuracion as shown in the GASSAR-6 docunent ${ }^{3}$ for the analysis of any accident involving loss of cooling in the main loop.

HEXEREI2 can also be used to evaluate the detailed performance of the FSV core and primary loop during abnoraal cransier.ts; however, additional cise-dependent information such as the fraction of the stean generator bundle that is flooded plus information on circulator operation must be provided. At present, it will not perform these analyses as a standalone computation.

The FLODIS-CCCY combination, ${ }^{7-9}$ and nore recently the expanded FoDis calculation, 10 can perfor decailed theral-hydraulic analyses for the FSV core plus the surroundings. Input detailing the total net flow into this cavity and the inlet temperature as a function of tine during the transient is required for these calculations. Certain assuaptions that are used to determine the intelal temperature distribution in the cavity and core are built into the calculations; these cemperatures constitute the initial conditions on which the cransient cenperatures are based. Thus, FLODIS performs the calculation for the FSV core in somewhat the same manner that GAC uses in Its RECA code. However, the FLODIS representation of the core is wore detalled and realistic and should produce values for fuel and outlet gas cemperatures that are more useful for licensing analysis. Although RECA is a conservative model for some transients, it appears that it will not be conservative for other postulated accident sequences. 
In June 1976, correlations were provided by CaC based on experianencs: operation of the test for FSV orifice assembly. Prior to chat tien, general correlations for circular orifice plates, wich obviously had linited application, had been used. The new correlations have been substituted in the flow calculations for both the Hexenel2 codel7 and the FLODIS code. 10 When comparisons of results from hexEnel2 and FooIs uith those fron the RECA calculation are possible, good agreement is found in the evaluation of overall presstre luss across the core for significant flows, but the distribution of flow produced when "nearly closed" orifices are required does not agree.

It should be noted that echanical moveneat of the orifice device can completely cover the rectangular orifice openings. A ninime flou area is provided by the clearances beiween the various parts of the assembly and between the upper plenu elemats.

Current calculations differ for the partial refueling regions at the core-reflector boundary. These partial regions, which have less than seven fuel coluans, have the same crifice mechanisa as the complete region. It is obvious that these partial regions will always be operated with the orifice mechanisa in a more closed position as compared with the complete region. In fact, in eany cases the orifice mechanisa will be in the fully closed position and still will not restrice the flow sufficiently to producz an outlet temperature from the region equai to the mean exit coolant temperature.

Again, the HEXEREI2 and FLODIS calculations do not correspond =0 the RECA results. It is possible that in che fully closed position, a different representation of the "orifice loss" is required.

\subsection{Review of Large HTCR Performance}

HEXEREI2 can he used to evaluate ail abnormal transfents for large HTGR desigra in which there is immediace loss of main-loop cooling ( $($ mLC). The cure representacion is "huilt up" by the program from overall parameters such as tocal core powr?, fuel element size, and cotal core dimensions. It is assumed that the reactor is brought to subcriticality simultaneously with the Lomlc; however, the inftiation of 
CACS operation can be delayed for a spe. if ied period. Certain information, suit. as the inlet temperature and flow of cooiant vater to the cacs heat exchanger, must be specified.

The performance linitations of the electric motor drive for the cacs circulator are built into the code and must be changed internally if these features are altered. Control features that will regulate the circulator speed to maintain an out let water temperature from the CACS heat exchanger of $478 \times\left(400^{\circ} \mathrm{F}\right)$ or less are built into the code. The required circulator motor speed, torque, and power are indicated.

A feature that is not included in the HEXERE12 code ${ }^{17}$ at present is the incernal ability to calculate the rate of air ingress following a depressurization accident. This rate of air ingress is calculatec by a separate computation called IMGRES. ${ }^{19}$ The calculation could be run separately, and provisions are ade in HEXEREI2 to specify the effective molecular wetgint of the coolant as a function of tiene during a depressurization accident. The INGRES calculation cculd be added as a subroutine in the HEXEREI 2 computation with relatively litcle additional effort.

Since most of the ultimate licensing questions involve the evaluation of protection of the public, it is the performance of the cacs system that must be investigated to resolve most questions of this type. Operation of the main-loop cooling systems for any period of tine followng reactor trip will result in lower inftial cemperatures and smaller potentiaj heat sources than will be found in those analyses depending only upon heat removal by the CACS. It can be assumed in those cases that thermal cranslents will be less severe.

The HEATUP code $^{5}$ deteraines the thermal conditions for the ultimate accident when all forced convective cooling is lost during the heat-up pe: fod. The HEATUP calculation implies shat depressurization has occurred, since the transport of heat by natural convection currents within the core cavity is neglected. As ncted in this report, the HEATUP code can associate the calculated temperature of the fuel with the age of the fuel (1.e., its exposure to irradiation). Cinerally, the older fuel will be operating at lower power densities and, therefore, will heal. up more slowly than the newer fuel. The 1rradiated fuel does fall at lower temperatures. Heat removal from the perimeter of the core is neglected in 
this calculation, since for large HTGR cores, sublimation temperatures for graphite are reached before significant amounts of heat are removed from the perineter. The specified 20 to 107 uncertainty in afterheat generation is not incorporated in this code and should be added.

\subsection{Computational Techniques Available from Orher Codes}

During the sase period in which the above work was being done, parallel work concerning the safety of HTCR designs was initiated at ORWL under sponsorship of the Division of Reactor Safety Research of the U.S. Nuclear Regulatory Comission. One of the intitial objectives of that progran was to evaluate computational methods for safety analysis developed by GaC. Durłag the interval between the assigment of the task and the transmittal by GAC of detailed listings and inforation about the computer prograns, members of the staff of ORNL undertook to develop sinilar computational methods from the general descriptions of the codes that existed in the open literature. The purpose of this effort was to add to our overall understanding of the problems involved in the development of these computational methods and to have known methods available for use in the execution of comparison cases.

In February 1976, representatives of the Division of Systems Safety made a direct request to the Chief of the Experimental Gas-Cooled Reactor Safety Research Branch of the Division of Reactor Safety Research to have this effort at ORWL directed toward the development of a specific cotalsystem performance code for the fort St. Vrain reactor. In response to this request, a code called ORTAP, which was written to perform the same type of computations as the TAP code of GAC, was modifled to represent the primary circuit and BOP for the FSV plant. This code includes a single-channel model for the core [CORTAP (Ref. 19)] that is coupled with point neutronic calculations; it also includes detailed representations of the steam generator [BLAST (Ref . 20)], the main hel fum circulator, and the BOP.

At the same time, the ORECA $\operatorname{code}^{13}$ was developed specifically to model the core of the PSV reactor in a manner similar to characteristics described for RECA. The cask of coupling ORECA with ORTAP to provide a 
complete calculation for all transients is yet to be completed. It should be rewenbered that FSV, unlike the large HTCRs, does not have an auxiliary cooling loop. FSV depends upon the use of an auxiliary drive for the ain circulators plus the flooding of the stean generators to remove the afterheat in an emergency situation.

Another Important point is that ORTAP and ORECA were developed as best-estiate calculations with the original purpose of providing comparison calculations for the corresponding CAC codes. Tiiis method of development differs from the procedures used to develop computational methods for the licensing division. The latter procedures were developed in such a manner that the results would always be conservative, and they were also conpared, when possible, with other computational techniques at each stage of development.

Additional work is requited for the ORECA code to include the modified orifice correlations that were provided by GAC in June 1976.

A comparison of calculated prinary loop flows for the DBDA in the FSV with reactor trip from 402 power identified two bypass streans that are included in the TAP calculation but not in any ORT calculations. These bypass flows occur at the bottom of the core barrel and at the lower support floor. The first flow bypasses the core, and the second bypasses both the core and the stean generator. Drawings giving physical dimensions of these structures were provided by GAC in June 1976; these dimensions will be used to estimate the anount of bypass flow, and she information will be added to ORTAP.

The GAC-FSV version of TAP also represents the heat lost to the PCRV liner cooling system as the gas returns to the core inlet from the circulator discharge. This effect is not represented in the current version of ORTAP.

The current plan is to obtain operational data frow the FSV plant for the verification of both ORTAP and ORECA, in total and for individual parts, for all transients that can reasonably be executed. In the interim, comparison cases can be executed using ORECA, HEXEREI2, and the expanded version of FLODIS. 


\subsection{Conclusions}

1. For current detailed analysis of thermal conditions in the FSV core during low-flow conditions, either FLODIS or HEXEREI2 can be used as the basis for licensing decisions.

2. HEXEREI2 can be used co evaluate FSV primaty loop perfornance only if additional transient information is avallable.

3. HEXEREI2 can be used for LOALC and coincident reactor trip for large HTGR designs, except for depressurization accidents. For chese accidents, IMGRES mast be executed separately and the results entered into HEXERE12. These two calculations should be merged into one program.

4. Additional modifications of ORECA are required to incorporate che experimental orifice coefficient relationships provided by Gac.

5. Modifications of the present version of DRTAP are required to represent the two bypass streans and the heat loss from the circulating gas to the PCRV-liner cooling system.

6. ORECA and ORTAP can be executed for FSV transient analysis on a best-estinate basis. These two calculations are being merged. The combined code will be verified with experimental data from FSV.

7. Temporary modifications were previously ade in ORECA to determine temperatures in the PCRV during a temporary loss of PCRV-liner cooling capability. General linits wust be defined for this accident, and permanent modifications must be ade to accomodate a range of problems of this type. 


\section{REFERENCES}

1. Delmarva Power and Light Company, Str:

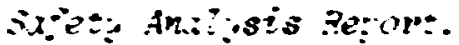

2. Philadelphia Electric Company, Fulton jenerating Stdion, Preiminar: Sijety Anzijois Regurt.

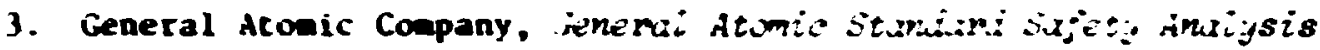

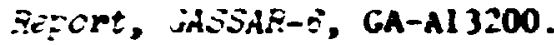

4. K. E. Schwarczcrauber and F. A. Silady, CORCON: i Sronmom for Ana issis OH:JR Core Heatup Transients, GA-A12868 (GA-LTR-13) (July 15, 1976).

5. I. I. Siman-Tov and W. D. Turner, HEATIP - A Computer Prograr for the Pinema: Anal 8 sis of a LOFC Accident in an HTCR, ORNL/CSD/TM-16 (co be published).

6. W. D. Turner, HEATIMGS - An IBM 360 Heat Corduction Progrom, ONu/ CSD/Mi-15 (to be published).

7. J. P. Sanders et al., Evalwation of Thermal Response in Fort St. Lrain Reactor Primary System tc a Jesi.jm-Basis D. ressurization Accicient Eullowed bi Cooling with Two Pelton Wheel Drives at $7000 \mathrm{rpm}$, OSN./TH-5140 (Decenber 1975).

8. H. D. Turner and J. P. Sanders, CCCM - i Single-Channel, Coutled, Conduction-Convection Model for Use in Themai Ancl isis in Hi.jhTemperature Gas-Cooled Reactors, ORm/CSD/MM-23 (to be published).

9. D. D. Paul, FLODIS: A Computer Model to Determine the Flow Distribution and Thermal Response of the fort St. Vruin Reactor, ORm./TH5365 (June 1976).

10. D. D. Paul, Jepressurization Accident Analyses for the Fort it. Vrain ?eactor, ORNL/AUREC/Mi-58 (December 1976).

11. H. H. Chi and G. J. Malek. Description of the Reactor Emergency Cooling Analysis Code, RECA, GA-10273 (Aug. 19, 1970).

12. A. Bardia and R. C. Potter, TAP: A Progron for Anaitsis of HTGR Muclear Stean Supply System Performance Transients, GA-A13248 (GA-LTR-21) ('an. 30, 1976).

13. S. J. Ball, ORECA-I: A Digital Computer Code for Simulating the Dynomics of itTCR Cores for Bmergency Cooling Analy es, ORM/TM-5159 (Apri1 1976).

14. Letcer froa R. F. Halker, Vice President, Public Service of Colorado, to R. A. Clark, Chief, Gas-Cooled Reactors Branch, Division of Reactor Licensing, USINRC, Feb. 28, 1975, Docket No. 50-267.

15. Letter from J. P. Sanders, Oak Ridge National Laboratory, co W. Gilbert, Project Manager, Special Reactor Branch, USWRC, June 1, 1976; Subject: "Inforation Obtained from GAC on Safety Analysis of HTCRs"; Docket No. 50-267. 
16. Letter (witli attachment 2 only) fron R. F. Halker, Vice President, Public Service of Colorado, to R. P. Dense, Assistant Director for Advanced Reactor Concepts, USNRC, Dec. 20, 1975; Subject: "Linfting Power Level Pr cor to Availability of Interin Alcernate Cooling Method": Docket No. 50-267.

17. G. E. Giles et dl.. HEXEPE!2: Computer Program for the Transient The mal tigdraui in andissis of high Temperature Gas-Coo'ed Reactors, $\mathrm{K} / \mathrm{CSD} / \mathrm{MM}-3$ (to be published).

18. R. L. Reid and J. P. Sanders, INCRES: A Computer Cocie for the Rate

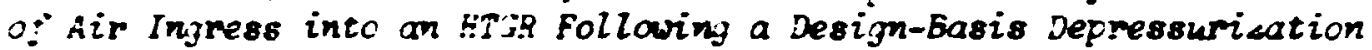
Acicient, ORN//M-5144 (Decenber 1975).

19. J. C. Cleveland, CORTAP: A Coupled Neutron Kinetics-Heat Transfer Digital Computer Progran for the Dynamic Simulation of the HTOR Core, ORNL/MUREG/Mi-39 (to be published).

20. R. A. Hedrick and J. C. Cleveland, BLAST: A Digital Computer Progrom for the Dynamic Simuiation of the High-Temperature Gas-Cooiec Reactor Reheater-stean Gererator Module, ORNL/NuREc/mi-38 (August 1976). 